ANETA MAKOWSKA

Uniwersytet Szczeciński

\title{
NADANIE TYTUŁU DOKTORA HONORIS CAUSA UNIWERSYTETU SZCZECIŃSKIEGO PROF.ZW. DR. HAB. ZBYSZKO MELOSIKOWI
}

Osiemnastego października 2018 roku podczas uroczystego posiedzenia Senatu Uniwersytetu Szczecińskiego odbyła się uroczystość nadania tytułu doktora honoris causa prof. zw. dr. hab. Zbyszko Melosikowi. Promotorką w procesie nadania tytułu była dr hab. Urszula Chęcińska, prof. US, recenzentami profesorowie: prof. zw. dr hab. Marek Konopczyński (Uniwersytet w Białymstoku), prof. zw. dr hab. Barba-

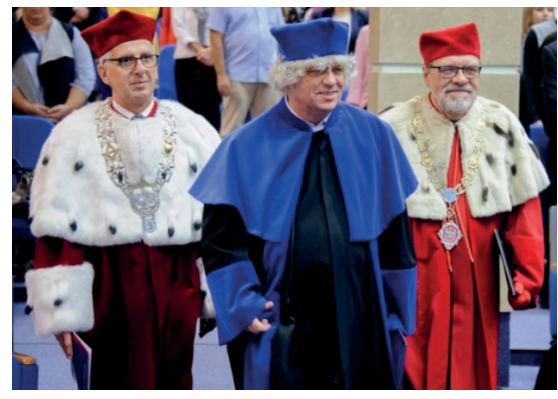

Fot. Filip Kacalski ra Kromolicka (Uniwersytet Szczeciński) oraz prof. zw. dr hab. Bogusław Śliwerski (Uniwersytet Łódzki).

Otwierając uroczystość, Jego Magnificencja Rektor Uniwersytetu Szczecińskiego Pan Profesor Edward Włodarczyk podkreślił, że uhonorowanie najwyższą godnością akademicką Pana Profesora Zbyszko Melosika przywołuje szczególne związki Uniwersytetu im. Adama Mickiewicza w Poznaniu i Uniwersytetu Szczecińskiego. Działalność Wyższej Szkoły Nauczycielskiej w Szczecinie, filii UAM w Poznaniu (od 1973 roku Wyższej Szkoły Pedagogicznej) była jednym z filarów utworzonego w latach osiemdziesiątych Uniwersytetu Szczecińskiego: „(...) to właśnie Uniwersytet Poznański pomógł środowisku naukowemu Szczecina zaistnieć na mapie naukowej Polski. Jesteśmy wdzięczni za ten wkład i stąd Uniwersytet Szczeciński wyrażał to, nadając tytuły doktorów honorowych naszej uczelni między innymi dwóm przedstawicielom środowiska poznańskiego: profesorowi Gerardowi Labudzie i wspaniałemu prawnikowi Zbigniewowi Radwańskiemu. Dzisiaj ten tytuł dla Pana Profesora Zbyszko Melosika jest potwierdzeniem związków Szczecina z Poznaniem. Związków, chciałbym tu powiedzieć, już w tej chwili mocno partnerskich". 
Pan Profesor Zbyszko Melosik od początku swojej pracy naukowej związany jest z Uniwersytetem im. Adama Mickiewicza w Poznaniu. Jest absolwentem studiów politologicznych na Wydziale Nauk Społecznych UAM oraz studiów doktoranckich w Instytucie Socjologii UAM. W 1995 roku na podstawie rozprawy „Współczesne amerykańskie spory edukacyjne” otrzymał stopień doktora habilitowanego $\mathrm{w}$ dziedzinie nauk humanistycznych $\mathrm{w}$ dyscyplinie pedagogika a już trzy lata później, w 1998 roku tytuł naukowy profesora. Należy do wielu ogólnopolskich i światowych gremiów naukowych i akademickich, m.in. Centralnej Komisji ds. Stopni i Tytułów, jest wieloletnim członkiem (a aktualne wiceprzewodniczącym) Komitetu Nauk Pedagogicznych PAN, prezesem Polskiego Towarzystwa Pedagogiki Porównawczej, ekspertem Narodowego Centrum Nauki i Narodowego Centrum Badań i Rozwoju, członkiem norweskiej Agder Academy of Science and Letters, stypendystą Fundacji Fulbrighta, profesorem wizytującym na University of Virginia. Przez dwie kadencje, w latach 2008-2012 i 2012-2016 pełnił funkcję Dziekana Wydziału Studiów Edukacyjnych Uniwersytetu im. Adama Mickiewicza. Pan Profesor jest promotorem dziewiętnastu dysertacji doktorskich, a pięciu spośród wypromowanych doktorantów uzyskało stopień doktora habilitowanego.

Dorobek naukowy doktora honoris causa koncentruje się wokół filozofii i socjologii edukacji oraz pedagogiki porównawczej. Pan Profesor podejmował badania m.in. nad rolą filozofii postmodernistycznej i jej znaczenia dla rozwoju myśli pedagogicznej, czynnikami rozwoju tożsamości, selekcyjną i socjalizacyjną funkcją edukacji, znaczeniem kultury popularnej w procesach socjalizacyjnych i edukacyjnych, współczesną rolą uniwersytetu. Spośród wielu publikacji Pana Profesora należy wymienić przynajmniej: „Współczesne amerykańskie spory edukacyjne” (1995), „Postmodernistyczne kontrowersje wokół edukacji” (1995), „Tożsamość, ciało i władza. Teksty kulturowe jako (kon)teksty pedagogiczne” (1996), „Kryzys męskości w kulturze współczesnej” (2002), „Teoria i praktyka edukacji wielokulturowej” (2007), „Uniwersytet i społeczeństwo. Dyskursy wolności, wiedzy i władzy” (2009), „Kultura popularna i tożsamość młodzieży. W niewoli władzy i wolności” (2013), „Piłka nożna. Tożsamość, kultura i władza” (2016).

Promotorka przewodu - Pani Profesor Urszula Chęcińska - w wygłoszonej podczas uroczystości laudacji podkreśliła zarówno niekwestionowaną wartość dorobku naukowego Pana Profesora, jak i wyjątkowy sposób jego prezentacji: „(...) we wszystkich wymienionych publikacjach szczególną wartość stanowią głęboki humanistyczny namysł twórczy, wnikliwość krytyczna i oryginalność myślenia połączona z oryginalnością formy literackiej. (...) Zbyszko Melosik, wszechstronne wykształcony poznański uczony z pokolenia humanistycznego w kongenialny sposób łączy więc etykę z poetyką, kulturę wysoką z kulturą popularną, nauki humanistyczne $\mathrm{z}$ naukami społecznymi, żongluje mini - jak sam to określił w rozmowie - jak piłką nożną. Obok wielkich dzieł klasyki światowej: Szekspira, Dostojewskiego, Miłosza pojawiają się w jego tekstach, na równych prawach, wartości w stylu pop. Słowa Madonny, Michaela Jack- 
sona i zespołu U2. Jak w kolażach Wiesławy Szymborskiej, które stanowią swoisty aneks do jej wierszy, pełny przesłań moralnych i głębokich filozoficznych myśli. Nie ma tekstów wyższych i niższych. Lepszych czy gorszych, są teksty innych ludzi posługujących się mniej czy bardziej oderwaną od codzienności estetyką - czytamy w tomie „Tożsamość - Kultura - Edukacja”.

O bohaterze uroczystości Pani Profesor Urszula Chęcińska mówiła:

„(...) Uprawianie nauki jest dla Pana Profesora Zbyszko Melosika potrzebą naturalną, wynikającą z dialogicznej mentalności, z wrażliwości estetycznej, ze swoistej pedagogicznej artrologii przynależnej do filozoficznego myślenia i postrzegania świata. Granice mojego języka wyznaczają granice mojego świata, a jeżeli ten świat jest światem Profesora Zbyszko Melosika to jest to świat mądry, szlachetny i piękny, bo taki jest Profesor Zbyszko Melosik. Dysponując osobistym, ogromnym potencjałem humanistycznym wynikającym najpierw z radości czytania, a potem z radości pisania Zbyszko Melosik obmyśla świat wydanie drugie, poprawione. (...) Świat ponowoczesności, w którym nie działają już stare struktury i zasady, a społeczeństwo jest w stanie permanentnego oblężenia i płynności, potrzebuje jak nigdy dotąd mądrej, pedagogicznej refleksji. Takiej, którą od lat uprawia Pan Profesor Zbyszko Melosik. Refleksji wynikającej z twórczych zachowań człowieka, z filozoficznego jasnosłyszenia, z aktywności ludzkiego ducha, pozwalającej na swobodę manipulowania językiem, wyobraźnią i emocjami. Jestem o tym głęboko przekonana".

Po wygłoszeniu laudacji Rektor Uniwersytetu Szczecińskiego Pan Profesor Edward Włodarczyk odczytał uchwałę nr 89/2018 Senatu Uniwersytetu Szczecińskiego z dnia 27 września 2018 r., uchwalającą nadanie prof. dr. hab. Zbyszko Melosikowi tytułu doktora honoris causa Uniwersytetu Szczecińskiego, a Pani Profesor Urszula Chęcińska odczytała łacińską treść dyplomu, który został uroczyście wręczony Panu Profesorowi Zbyszko Melosikowi.

Następnie doktor honoris causa Uniwersytetu Szczecińskiego został poproszony przez JM Rektora Uniwersytetu Szczecińskiego o wygłoszenie wykładu, który rozpoczął słowami:

„Słowa magiczne w naszym życiu, słowa, które elektryzują, słowa symbole, słowa, które społeczeństwo darzy szacunkiem, słowa, które same w sobie są optymistyczne, bowiem zawierają obietnicę i nadzieję. Są takie słowa. Tak, Uniwersytet to słowo magiczne. Słowo, które przemawia do wyobraźni. Uniwersytet to słowo optymistyczne, to słowo wymawiane z szacunkiem. I właśnie dzisiaj, w kulminacyjnym i jakże optymistycznym momencie mojej biografii, odbieram na znakomitym Uniwersytecie Szczecińskim, największą godność akademicką doktora honoris causa. I właśnie dzisiaj spotyka mnie ten ogromny zaszczyt i honor, że ten uniwersytet docenił mnie, obdarzył mnie zaufaniem, nagrodził mój biograficzny wysiłek akademicki (...)”.

Podczas wystąpienia Pan Profesor podkreślał m.in. konieczność kontynuacji kultury szelestu kartek, postulował pedagogikę rdzenia tożsamości, koncentracji uwagi i kontemplacji. Wykład przepełniony był wiarą w uniwersytet rozumiany nie jako miejsce algorytmizacji i parametryzacji, ale jako ponadczasowe idee i wartości, które wiążą biografie naukową i życiową. Doktor honoris causa rysował przed słuchaczami ścieżki i zaułki pracy akademickiej, których siłą napędową jest pasja: 
„Są bowiem wartości, które trwają i przetrwają, stanowią bowiem rdzeń naszej tożsamości akademickiej. Są to wartości, które nadają sens i wyznaczają trajektorie naszych akademickich biografii. Jestem pewien, że wszyscy zgromadzeni na tej sali znakomicie percypują pojęcie pasja, zarówno w kontekście intelektualnym, jak i emocjonalnym. Pasja stanowi krystalizację naszej akademickiej tożsamości. Po pierwsze, to pasja uprawiania nauki, od powstania w umyśle naukowca problemu badawczego aż do opublikowania wyników prowadzonych badań. Przekraczanie granic wyobraźni, odkrywanie nowej prawdy o świecie i konstruowanie jej w nową wiedzę stanowi proces i nie jest nagłym aktem. Wyjątek eureki Archimedesa tylko potwierdza tę regułę. W trakcie tego procesu myśl naukowca, czy to fizyka eksperymentatora w laboratorium, czy historyka cierpliwie studiującego dawne rękopisy, przekształca się i dojrzewa. Niekiedy powraca on już do odrzuconych idei i pomysłów, niekiedy mknie jak porsche na autostradzie po to, by stanąc nagle przed czerwonym znakiem zakazu, bo okazało się, że to nie ta droga. Aż w końcu naukowiec w wyniku długotrwałych, systematycznych dociekań podejmuje decyzję, czas opublikować wyniki badań. Cały czas przy tym dynamika jego działań definiowana jest przez pasję, kreującą nieustanną motywację, pozytywny skok adrenaliny (...). Wspólna pasja w zakresie uprawiana nauki jest jednym z najważniejszych źródeł istnienia naszej wspólnoty akademickiej. Zarówno w ramach poszczególnych dyscyplin jak i uniwersytetów, na poziomie kraju i w sensie ogólnoświatowym, globalnym. To nas wyróżnia akademicka wspólnotowość. Posiadamy unikatową władzę i wolność kreowania wspólnot, których znakomitą krystalizacją jest nasza obecność na dzisiejszej uroczystości. Drugi kontekst pasji związany jest z przekazywaniem wiedzy, kompetencji i wartości studentom podczas wykładów i seminariów. Wówczas to urzeczywistniana jest nasza odpowiedzialność za kształtowanie tożsamości młodych ludzi stanowiących integralną część wspólnoty akademickiej (...)”.

Uroczystość uświetnili swoją obecnością: Rodzina Pana Profesora, rektorzy uczelni wyższych i dziekani wydziałów nauk humanistycznych i społecznych, dyrektorzy instytutów pedagogicznych i edukacyjnych z całej Polski oraz licznie zgromadzeni studenci i studentki. Pan Profesor Zbyszko Melosik zakończył swój wykład składając szczególne podziękowania dwóm osobom: „(...) [W] autobiograficznej refleksji powstaje zawsze pytanie o znaczące osoby we własnym rozwoju naukowym. Mógłbym tutaj przywołać dziesiątki nazwisk teoretyków i badaczy rzeczywistości edukacyjnej i społeczno-kulturowej, którzy wywarli na mnie wpływ: od Talcotta Parsonsa, przez Pierre'a Bourdieu, Micheala Foucaulta do Lawrence'a Grossberga. Chciałbym jednak przywołać nazwiska dwóch osób, które towarzyszyły mi nieustanne w mojej akademickiej biografii. Pierwsza z tych osób to Profesor Bogusław Śliwerski, z którym przyjaźń, nie tylko akademicka, wywarła niezaprzeczalny wpływ na moją tożsamość naukową. Dziękuję bardzo Bogusiu! Druga z nich to Profesor Zbigniew Kwieciński, pierwszy dziekan Wydziału Studiów Edukacyjnych, który zawsze we mnie wierzył a jego przenikliwe inspiracje były dla mnie zawsze źródłem wielu nowych pomysłów naukowych. Dziękuję Zbyszku!”.

Uroczystość była spotkaniem uhonorowującym imponujący dorobek naukowy Pana Profesora, ale także okazją do odsłonienia kulis warsztatu - radości, trudów i dylematów - pracy akademickiej. Pozwoliła także na ukazanie mniej znanych obszarów działalności i życia Pana Profesora, np. znaczącego wkładu 
w edukację funkcjonariuszy służb mundurowych i wspieranie miesięcznika „Policja 997” (odczytano list gratulacyjny od Komendanta Głównego Policji) lub uwielbienia dla pizzy ziemniaczanej, którą wspominał jeden z doktorantów Pana Profesora, dziś dr hab. Maciej Bernasiewicz.

Całość dorobku Pana Profesora, ale także postawę i sposób uprawiania nauki, który zaowocował nadaniem Panu Profesorowi tytułu doctora honoris cousa najpiękniej może podsumować ponowne przywołanie fragmentu laudacji:

„(...) Uprawianie nauki jest dla Pana Profesora Zbyszko Melosika potrzebą naturalną wynikającą z dialogicznej mentalności, z wrażliwości estetycznej, ze swoistej pedagogicznej artrologii przynależnej do filozoficznego myślenia i postrzegania świata. Granice mojego języka wyznaczają granice mojego świata, a jeżeli ten świat jest światem Profesora Zbyszko Melosika, to jest to świat mądry, szlachetny i piękny, bo taki jest Profesor Zbyszko Melosik. Dysponując osobistym, ogromnym potencjałem humanistycznym wynikającym najpierw z radości czytania, a potem z radości pisania, Zbyszko Melosik obmyśla świat wydanie drugie, poprawione. (...) Świat ponowoczesności, w którym nie działają już stare struktury i zasady, a społeczeństwo jest w stanie permanentnego oblężenia i płynności, potrzebuje jak nigdy dotąd mądrej, pedagogicznej refleksji. Takiej, którą od lat uprawia Pan Profesor Zbyszko Melosik. Refleksji wynikającej z twórczych zachowań człowieka, z filozoficznego jasnosłyszenia, z aktywności ludzkiego ducha, pozwalającej na swobodę manipulowania językiem, wyobraźnią i emocjami. Jestem o tym głęboko przekonana"'.

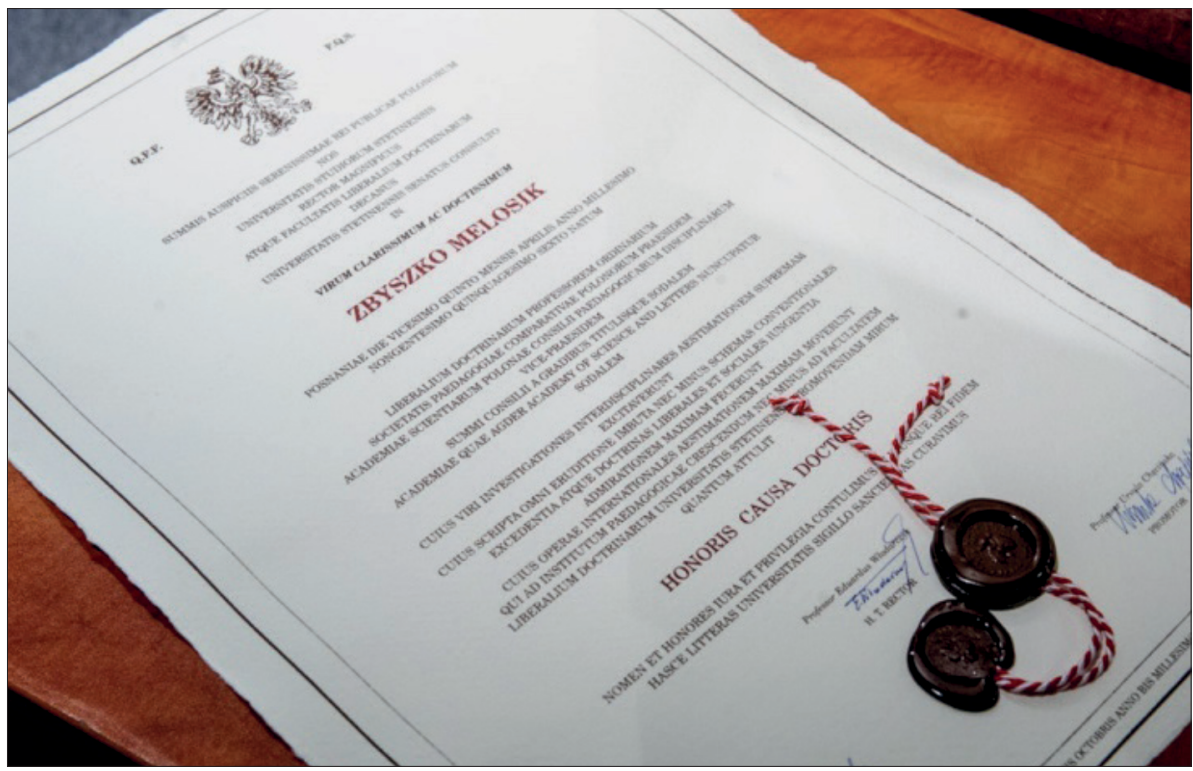

Fot. Filip Kacalski

1 Wszystkie cytaty są transkrypcją nagrania z uroczystości, którą można obejrzeć na kanale YouTube Uniwersytetu Szczecińskiego: https://www.youtube.com/watch?v=I7E_T9s5_IE\&t=5475s [dostęp: 29.11.2018]. 